\title{
Pseudomonas pertucinogena sp.nov., an Organism Previously Misidentified as Bordetella pertussis
}

\author{
YOKO KAWAI AND EIKO YABUUCHI \\ Department of Bacteriology I, National Institute of Health, Shinagawa-ku, Tokyo, 141, Japan, and \\ Department of Microbiology, Kansai Medical School, Moriguchi-city, Osaka, 570, Japan
}

The morphological and biochemical attributes of two organisms, American Type Culture Collection (ATCC) strains 190 and 6627, originally identified as Bordetella pertussis, were studied. The guanine-plus-cytosine content of the deoxyribonucleic acid of each strain is $60 \mathrm{~mol} \%$. The deoxyribonucleic acid homology between the two strains is $99 \%$. The strains are quite similar phenotypically and genetically, and they are regarded here as belonging to one and the same species. Although the two strains produce pertucin, a bacteriocin active against $B$. pertussis strains in the smooth phase, they possess the characteristics of the genus Pseudomonas as defined by Shewan and Haynes. However, ATCC 190 and 6627 could not be placed in any of the Pseudomonas species described in the literature. Therefore, these strains are regarded as belonging to a new species, for which we propose the new name Pseudomonas pertucinogena. The type strain of $P$. pertucinogena is ATCC 190.

For many years, American Type Culture Collection (ATCC) 190 and ATCC 6627, two motile, polar monotrichous organisms, have been unwittingly accepted as rough phase IV Bordetella pertussis strains (21); Kawai (18) and Aprile (2) recognized this enigma. The two strains produce pertucin, a bacteriocin that inhibits the growth of smooth strains of $B$. pertussis. Although the colonial morphology of these strains is similar to that of rough strains of $B$. pertussis, the motility, flagellar morphology, and guanine-plus-cytosine $(\mathrm{G}+\mathrm{C})$ content of their deoxyribonucleic acid (DNA) distinguish them from smooth and rough strains of $B$.pertussis. Their polar monotrichous anatomy and other attributes suggest that they are pseudomonads. In our opinion, these strains do not belong to any of the Pseudomonas species described in Bergey's Manual of Determinative Bacteriology (6). Although these strains were referred to by the name Pseudomonas pertucinogena in a previous publication (19), the name was only mentioned incidentally and therefore was not validly published. The purpose of this paper is to effect the valid publication of the name and to provide a description of the species.

\section{MATERIALS AND METHODS}

Bacterial strains. The designations and sources of the 16 strains included in this study are listed in Table 1 .

Methods. The morphological, physiological, and biochemical characteristics of ATCC 190 and ATCC 6627 were determined primarily by methods described previously (40). Acid production from glucose and 25 additional carbon compounds was deter- mined in oxidation-fermentation basal medium (Difco 688) and cystine-tryptone agar (Eiken). Antibiotic susceptibility tests were performed as described previously (40). In determinations of sole carbon and energy sources, each of 47 carbon compounds was added to a standard mineral base (34) in a concentration of $0.1 \%$. Growth was harvested from a 24-h-old brain heart infusion agar culture and suspended in sterile saline solution to a concentration of $10^{7}$ cells per $\mathrm{ml}$. Tubes of the 47 liquid media were inoculated with $0.05 \mathrm{ml}$ of this suspension, incubated at $37 \mathrm{C}$, and observed daily for 5 days. Culture media that became turbid within 24 to $48 \mathrm{~h}$ were serially subcultured.

G $+\mathbf{C}$ content of DNA. DNA extracted from cells grown on Cohen and Wheeler medium (8) slants was purified (36). The ultraviolet (UV) absorption spectrum of the DNA was determined in a recording spectrophotometer (Hitachi model 124). Phosphorus in the DNA was analyzed by Nakamura's modification (23) of the Allen method (1). Nitrogen was determined by the micro-Kjeldahl method. The purity of the DNA was confirmed by UV spectroscopy and by the N/P ratio. The melting temperature $\left(T_{m}\right)$ of the DNA was determined in $0.015 \mathrm{M}$ sodium chloride$0.0015 \mathrm{M}$ sodium citrate solution $(0.1 \times \mathrm{SSC})$ with a recording spectrophotometer (Shimazu model MPS$50 \mathrm{~L})$, by the method of Marmur and Doty (22) and Silvestri and Hill (33). The DNA was hydrolyzed with $88 \%$ formic acid at $175 \mathrm{C}$ for $30 \mathrm{~min}$ (39), and the paper chromatogram was developed with the solvent system isopropanol-6 $\mathrm{N}$ hydrochloric acidwater $(68: 16.4: 15.6, \mathrm{vol} / \mathrm{vol} / \mathrm{vol})$. UV spectroscopy was performed as described by Ulitzur (37).

DNA homology. All of the tested strains (see Table 7) except Pseudomonas fluorescens ATCC 13525 and Pseudomonas putida ATCC 12633 were grown at $37 \mathrm{C}$ with shaking to the logarithmic phase of growth. The growth medium had the following composition: $2 \%$ Casamino Acids solution treated 
TABLE 1. List of strains included in this study ${ }^{a}$

\begin{tabular}{|c|c|c|c|c|c|}
\hline \multirow{2}{*}{ Strain received as } & \multirow{2}{*}{$\begin{array}{l}\text { Received } \\
\text { from }\end{array}$} & \multicolumn{3}{|c|}{ Corresponding strain designation } & \multirow{2}{*}{ Status } \\
\hline & & ATCC & $\mathrm{KM}$ & Other & \\
\hline Bordetella pertussis, phase IV & ATCC & 190 & 1319 & & \\
\hline B. pertussis, phase IV & ATCC & 6627 & 1320 & & \\
\hline$B$. pertussis, phase I & Liu & 8467 & & & \\
\hline$B$. pertussis, phase I & NIHJ & & & 18323 & \\
\hline B. pertussis, phase III & IK & & & Sakurayashiki & \\
\hline$B$. pertussis, phase III & IK & & & $3 \mathrm{~B}$ & \\
\hline B. pertussis, phase IV & IK & & & Sakurayashiki & \\
\hline B. pertussis, phase IV & IK & & & Kudo & \\
\hline B. parapertussis & NIHJ & & & 17903 & \\
\hline B. bronchicanis & NIHJ & & & 214 & \\
\hline Pseudomonas aeruginosa & ATCC & 10145 & 274 & & Neotype \\
\hline P. fluorescens & ATCC & 13525 & 361 & & Neotype \\
\hline$P$. alcaligenes & ATCC & 14909 & 362 & & Neotype \\
\hline$P$. pseudoalcaligenes & ATCC & 17440 & 363 & & Type \\
\hline$P$. maltophilia & ATCC & 13637 & 418 & & Type \\
\hline P. putida & ATCC & 12633 & 888 & & Neotype \\
\hline
\end{tabular}

a Abbreviations: ATCC, American Type Culture Collection, Rockville, Md.; IK, Institute of Kitasato, Tokyo; KM, Kansai Medical School Culture Collection, Osaka; NIHJ, National Institute of Health, Tokyo.

with charcoal, $500 \mathrm{ml} ; \mathrm{NaCl}, 2.5 \mathrm{~g} ; \mathrm{MgCl}_{2} \cdot 6 \mathrm{H}_{2} \mathrm{O}$, $0.04 \mathrm{~g}$; $\mathrm{FeSO}_{4} \cdot 7 \mathrm{H}_{2} \mathrm{O}, 0.01 \mathrm{~g}$; L-cystine, $0.025 \mathrm{~g}$; soluble starch, $1.5 \mathrm{~g} ; \mathrm{K}_{2} \mathrm{HPO}_{4}, 4 \mathrm{~g} ; \mathrm{KH}_{2} \mathrm{PO}_{4}, 2 \mathrm{~g} ; 10^{-3} \mathrm{M}$ nicotinic acid solution, $10 \mathrm{ml}$; biotin $(5 \mu \mathrm{g} / \mathrm{ml}), 0.1$ $\mathrm{ml}$; and distilled water to make the total volume $1,000 \mathrm{ml}(\mathrm{pH} 7.0) \cdot\left[8-{ }^{14} \mathrm{C}\right]$ guanine or $\left[8{ }^{3} \mathrm{H}\right]$ guanine was added at a level of $0.2 \mu \mathrm{Ci} / \mathrm{ml}$, respectively. The $P$. fluorescens and $P$. putida strains were grown at $30 \mathrm{C}$. The DNA was extracted and purified as described previously $(31,36)$. DNA-DNA reassociation was performed by the membrane filter technique with formamide at low temperature $(24,36)$. Sheared, denatured ${ }^{14} \mathrm{C}$-labeled DNA (SD-DNA) of strains ATCC 190 and ATCC 17440 and ${ }^{3} \mathrm{H}$-labeled and immobilized DNA (IM-DNA) from each of the 12 strains tested were reassociated in a vibrating incubator at 45 or $37 \mathrm{C}$ for $24 \mathrm{~h}$. Each homology was performed in duplicate. The relative reassociation value of the DNA was calculated from the amount of SD-DNA reassociated per $2-\mu \mathrm{g}$ unit of IM-DNA retained on the membrane.

Reassociated homologous DNA of strain ATCC 6627 was compared with the reassociated heterologous DNA of ATCC 6627-ATCC 190 and ATCC 6627ATCC 13637 for the thermal dissociation profile by the method of Toyama et al. (36).

Serology. Rabbit antisera, homologous titers $1: 6,400$ and $1: 3,200$, specific for $B$. pertussis strains in phases I and III, respectively, were used for testing for the tube agglutination of ATCC 190 and ATCC 6627.

Animal inoculation. Strains ATCC 190 and ATCC 6627 were inoculated intravenously and intraperitoneally into mice. Cultures of each strain were suspended in saline at four concentrations $\left(10^{8}, 10^{9}\right.$, $10^{10}$, and $10^{11}$ cells $/ \mathrm{ml}$ ) and were used as inocula either as intact cell suspensions or cells disrupted by sonic treatment at 10 kcycles. A $0.1-\mathrm{ml}$ volume of each preparation was injected into the shaved skin on the back of two guinea pigs, and $0.25 \mathrm{ml}$ was injected intravenously or intraperitoneally into a mouse.

\section{RESULTS}

ATCC strains 190 and 6627 were gram-negative, non-encapsulated, asporogenous, straight rods. Soma size was about $0.4 \times 1.1 \mu \mathrm{m}$. Cells of both strains from solid and liquid media were motile and polar monotrichous. The flagellar morphology of each strain is shown in Fig. 1.

Both strains produced a slight, homogeneous turbidity in brain heart infusion broth after 24 $\mathrm{h}$ at $30 \mathrm{C}$. The turbidity increased after 2 days of incubation, but the broth did not become as turbid as that of a 24 -h-old culture of $P$. aeruginosa. Colonies on Bordet-Gengou medium after $24 \mathrm{~h}$ of incubation at $37 \mathrm{C}$ were grayish, $1 \mathrm{~mm}$ in diameter, and mimicked the colonies of rough phase IV strains of $B$. pertussis. Colonies of the two strains were less than $1 \mathrm{~mm}$ in diameter, semitranslucent, entire, smooth, and glistening on brain heart infusion agar, Trypticase soy agar, heart infusion agar, and nutrient agar. The biochemical reactions of the two strains are summarized in Tables 2 and 3 . Substrates utilized and those not utilized by the two strains as the sole carbon and energy sources are listed in Table 4.

Both strains were susceptible to 12 antibiotics, including penicillin, and were resistant to novobiocin (Table 5).

Specific antisera for $B$. pertussis failed to agglutinate either of the two strains.

Dermal necrosis in guinea pigs appeared at $24 \mathrm{~h}$ after injection of ultrasonically disrupted 


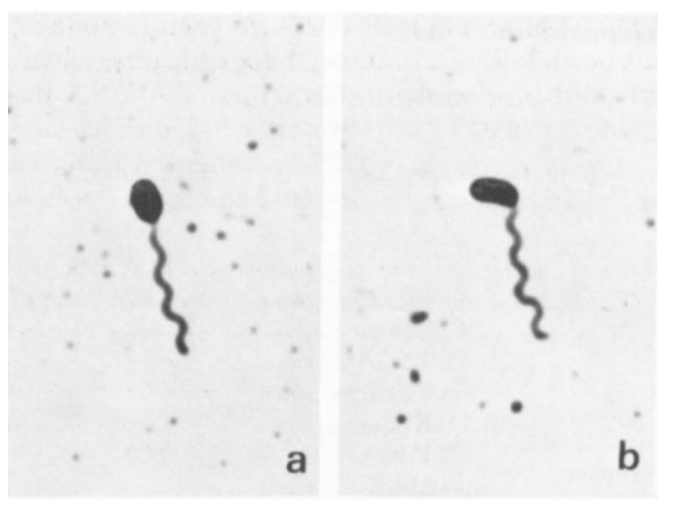

Fig. 1. Pseudomonas pertucinogena ATCC 190 (a) and 6627 (b). Broth culture. Leifson flagella stain after formalin fixation. $\times 2,000$.

cell suspensions of ATCC 190 and ATCC 6627 at a concentration of $10^{11}$ cells $/ \mathrm{ml}$. Sonically disrupted suspensions in lower concentrations of cells and whole-cell suspensions in four concentrations did not produce dermal necrosis in the guinea pig. Whole or ultrasonically disrupted cells of both strains at concentrations of $10^{11}$ cells per ml injected either intraperitoneally or intravenously appeared to weaken mice within $24 \mathrm{~h}$; the mice recovered and appeared healthy within $48 \mathrm{~h}$. Whole or sonically disrupted cells in lower concentrations did not kill mice during 10 days of observation.

The $\mathrm{G}+\mathrm{C}$ content of the DNA of ATCC 190 and of ATCC 6627 was $60 \mathrm{~mol} \%$, whereas the $\mathrm{G}+\mathrm{C}$ content of the DNAs of eight strains of three Bordetella species was around $67 \mathrm{~mol} \%$ (Table 6). DNA homology between strains ATCC 190 and ATCC 6627 was $99 \%$ at $45 \mathrm{C}$, the specific hybrid temperature. DNA homologies between ATCC 190 and the type or neotype strains of six Pseudomonas species at $45 \mathrm{C}$ are listed in Table 7. The thermal elution profile of ATCC 6627 SD-DNA reassociated with ATCC 190 IM-DNA was identical to that of the SDDNA of ATCC 6627 reassociated with homologous IM-DNA (Fig. 2).

\section{DISCUSSION}

During a survey for bacteriophages of Bordetella pertussis, Litkenhous and Liu (21) noted that strains ATCC 190 and ATCC 6627 produced a bacteriocin that inhibited the growth of $B$. pertussis strains. Kawai (19) reported the purification and characterization of pertucins produced by ATCC 190 and 6627 .

The ATCC received " $B$. pertussis" strain 2205 from the Eli Lilly Co. during March 1925, and this strain was assigned the ATCC accession
TABLE 2. Characteristics of ATCC 190 and ATCC $6627^{\prime 2}$

\begin{tabular}{|c|c|c|}
\hline Characteristic & ATCC 190 & $\begin{array}{c}\text { ATCC } \\
6627\end{array}$ \\
\hline $\begin{array}{l}\text { Gram-negative, rod-shaped } \\
\text { cells }\end{array}$ & + & + \\
\hline Single polar flagellum & + & + \\
\hline Motility & + & + \\
\hline $\begin{array}{l}\text { Indophenol oxidase and cata- } \\
\text { lase }\end{array}$ & + & + \\
\hline $\begin{array}{l}\text { Growth on LD agar and SS } \\
\text { agar }\end{array}$ & - & - \\
\hline $\begin{array}{l}\text { Growth on pseudosel agar and } \\
\text { on NAC agar }\end{array}$ & - & - \\
\hline Growth in BHI at $41 \mathrm{C}$ & + & + \\
\hline Growth in BHI at $\mathrm{pH} 4.5$ & - & - \\
\hline $\begin{array}{l}\text { Growth in BHI containing } 3 \% \\
\mathrm{NaCl}\end{array}$ & + & + \\
\hline Growth in KCN broth & - & - \\
\hline $\begin{array}{l}\text { Indole, methyl red, acetyl- } \\
\text { methylcarbinol }\end{array}$ & - & - \\
\hline $\begin{array}{l}\text { Simmons citrate, Christensen } \\
\text { citrate }\end{array}$ & - & - \\
\hline Malonate & - & - \\
\hline Kligler iron agar slant, acid & - & - \\
\hline $\begin{array}{l}\text { Kligler iron agar butt, acid } \\
\text { and } \mathrm{H}_{2} \mathrm{~S}\end{array}$ & - & - \\
\hline $\mathrm{H}_{2} \mathrm{~S}$, lead acetate paper & + & + \\
\hline Nitrate reduction to nitrite & - & - \\
\hline $\begin{array}{l}\text { Pigment production, water sol- } \\
\text { uble }\end{array}$ & - & - \\
\hline $\begin{array}{l}\text { Hemolysis around surface colo- } \\
\text { nies and green discoloration } \\
\text { of rabbit blood }\end{array}$ & - & - \\
\hline $\begin{array}{l}\text { Lysine decarboxylase, ninhy- } \\
\text { drin }\end{array}$ & - & - \\
\hline $\begin{array}{l}\text { L-Lysine, L-ornithine decar- } \\
\text { boxylase, Møller }\end{array}$ & - & - \\
\hline $\begin{array}{l}\text { L-Arginine dihydrolase, } \\
\text { Moller }\end{array}$ & - & - \\
\hline Phenylalanine deaminase & + & + \\
\hline $\begin{array}{l}\text { Acylamidase, urease, phospha- } \\
\text { tase }\end{array}$ & - & - \\
\hline $\begin{array}{l}\text { Deoxyribonuclease, extracellu- } \\
\text { lar }\end{array}$ & - & - \\
\hline $\begin{array}{l}\text { Hydrolysis of gelatin, starch, } \\
\text { Tween } 80\end{array}$ & - & - \\
\hline Growth in gluconate broth & - & - \\
\hline 2-Ketogluconate production & NT & NT \\
\hline $\begin{array}{l}\text { Growth at the expense of } p \text { - } \\
\text { hydroxybenzoate }\end{array}$ & - & - \\
\hline Cleavage of protocathecuate & NT & NT \\
\hline $\begin{array}{l}\text { Growth at the expense of } \beta \text { - } \\
\text { hydroxybutyrate }\end{array}$ & + & + \\
\hline $\begin{array}{l}\text { Accumulation of poly- } \beta \text {-hy- } \\
\text { droxybutyrate }\end{array}$ & - & - \\
\hline
\end{tabular}

a Symbols: +, positive reaction; -, negative reaction. Abbreviations: NT, not tested; BHI, brain heart infusion; SS, salmonella-shigella. 
TABLE 3. Acid production by ATCC 190 and ATCC 6627 from carbon compounds ${ }^{a}$

\begin{tabular}{|c|c|c|c|c|}
\hline \multirow{2}{*}{ Substrates } & \multicolumn{2}{|c|}{ ATCC 190} & \multicolumn{2}{|c|}{ ATCC 6627} \\
\hline & OF & CTA & OF & CTA \\
\hline $\begin{array}{l}\text { Ethanol, glyc- } \\
\text { erol }\end{array}$ & - & - & - & - \\
\hline $\begin{array}{l}\text { Adonitol, dulci- } \\
\text { tol }\end{array}$ & - & - & - & - \\
\hline $\begin{array}{l}\text { Inositol, man- } \\
\text { nitol, sorbi- } \\
\text { tol }\end{array}$ & - & - & - & - \\
\hline Xylose & $\mathrm{NC}$ & $\mathrm{WK}_{10}{ }^{b}$ & $\mathrm{NC}$ & $\mathrm{WK}_{10}$ \\
\hline D-Arabinose & $\mathrm{NC}$ & +20 & $\mathrm{NC}$ & $\mathrm{WK}_{10}$ \\
\hline L-Arabinose & $\mathrm{NC}$ & $\mathrm{NC}$ & $\mathrm{NC}$ & $\mathrm{WK}_{20}$ \\
\hline D-Ribose & $\mathrm{NC}$ & $\mathrm{WK}_{20}$ & $\mathrm{WK}_{20}$ & $\mathrm{WK}_{20}$ \\
\hline Rhamnose & - & - & - & - \\
\hline Glucose & $\mathrm{WK}_{7}$ & $+_{4}$ & $\mathrm{WK}_{8}$ & $+_{4}$ \\
\hline Fructose & - & - & - & - \\
\hline Galactose & $\mathrm{NC}$ & $t_{20}$ & $\mathrm{NC}$ & $\mathrm{WK}_{20}$ \\
\hline Mannose & $\mathrm{NC}$ & $\mathrm{WK}_{20}$ & $\mathrm{NC}$ & $\mathrm{NC}$ \\
\hline $\begin{array}{l}\text { Lactose, mal- } \\
\text { tose }\end{array}$ & - & - & - & - \\
\hline $\begin{array}{l}\text { Cellobiose, } \\
\text { melibiose su- } \\
\text { crose, treha- } \\
\text { lose }\end{array}$ & - & - & - & - \\
\hline $\begin{array}{l}\text { Raffinose, me- } \\
\text { lezitose }\end{array}$ & - & - & - & - \\
\hline Inulin, salicin & - & - & - & - \\
\hline $\begin{array}{l}\text { Basal medium, } \\
\text { control alka- } \\
\text { line }\end{array}$ & + & + & + & + \\
\hline
\end{tabular}

a Symbols: +, positive reaction; - , negative reaction. Abbreviations: NC, no change, WK, weakly positive reaction; CTA, cystine-tryptone agar (Eiken); OF, oxidation-fermentation basal medium (Difco 688).

${ }^{b}$ Figures indicate days required to obtain positive or weakly positive reaction.

number 190. On 26 October 1953, ATCC 190 was replaced by a strain, in the rough phase, received from Pearl R. Kendrick (University of Michigan School of Public Health). "B. pertussis," phase IV, was deposited by R. S. Muckenfuss, New York Department of Health, in the ATCC as strain 6627 on 3 May 1938.

Although the sources of isolation of the two strains were not recorded, their identification as strains of $B$. pertussis suggests that they were isolated from the human respiratory tract. Although identified as strains of $B$. pertussis, ATCC 190 and ATCC 6627 are motile by means of a single polar flagellum. They require molecular oxygen to oxidize glucose and other carbohydrates to acid without gas production, they fail to obtain energy by fermentation or photosynthetic metabolism, and the $\mathrm{G}+\mathrm{C}$ content of their DNA is about $60 \mathrm{~mol} \%$. Because of these findings, it seems reasonable to conclude that
ATCC 190 and ATCC 6627 are pseudomonads, not bordetellas. The morphological, physiological, and biochemical characters, the DNA homologies (99\%), and the thermal dissociation profile of reassociated DNA indicated that the two strains belong to one and the same species.

TABLE 4. Utilization of substrates by ATCC 190 and ATCC 6627 as the sole sources of carbon and energy

\begin{tabular}{|c|c|c|}
\hline \multicolumn{3}{|c|}{ Utilized } \\
\hline \multicolumn{3}{|l|}{$\begin{array}{l}\text { Amino acid } \\
\text { L- } \alpha \text {-Alanine } \\
\text { Organic acid } \\
\text { Pyruvate } \\
\text { Succinate } \\
\text { Oxaloacetate } \\
\beta \text {-Hydroxybutyrate }\end{array}$} \\
\hline \multicolumn{3}{|c|}{ Not utilized } \\
\hline $\begin{array}{l}\text { Amino acid } \\
\text { L-Glycine } \\
\text { L-Leucine } \\
\text { L-Isoleucine } \\
\text { L-Serine } \\
\text { L-Threonine } \\
\text { L-Valine } \\
\text { L-Aspartic acid } \\
\text { L-Glutamic acid } \\
\text { L-Proline } \\
\text { L-Tryptophane } \\
\text { L-Phenylalanine } \\
\text { L-Tyrosine } \\
\text { L-Histidine } \\
\text { L-Arginine } \\
\text { L-Lysine } \\
\text { L-Ornithine } \\
\text { L-Methionine } \\
\alpha-\text { Amino- } n \text {-butyric acid } \\
\beta \text {-Amino- } n \text {-butyric acid } \\
\gamma \text {-Amino- } n \text {-butyric acid }\end{array}$ & $\begin{array}{l}\text { Carbohydrate } \\
\text { D-Arabinose } \\
\text { L-Arabinose } \\
\text { D-Ribose } \\
\text { Xylose } \\
\text { Rhamnose } \\
\text { Glucose } \\
\text { Fructose } \\
\text { Galactose } \\
\text { Mannose } \\
\text { Lactose } \\
\text { Maltose } \\
\text { Cellobiose } \\
\text { Sucrose } \\
\text { Trehalose } \\
\text { Raffinose } \\
\text { Salicin } \\
\text { Inulin }\end{array}$ & $\begin{array}{l}\text { Alcohol } \\
\text { Ethanol } \\
\text { Polyalcohol } \\
\text { Adonitol } \\
\text { Inositol } \\
\text { Mannitol } \\
\text { Sorbitol } \\
\text { Dulcitol } \\
\text { Glycerol }\end{array}$ \\
\hline
\end{tabular}

TABLE 5. Susceptibilities of ATCC 190 and ATCC 6627 to antibiotics ${ }^{a}$

\begin{tabular}{lcc}
\multicolumn{1}{c}{ Antibiotic } & ATCC 190 & ATCC 6627 \\
\hline Ampicillin & +++ & +++ \\
Chloramphenicol & +++ & +++ \\
Colistin & +++ & +++ \\
Erythromycin & ++ & +++ \\
Gentamicin & +++ & +++ \\
Kanamycin & +++ & +++ \\
Nalidixic acid & ++ & ++ \\
Novobiocin & - & - \\
Penicillin & ++ & ++ \\
Polymyxin B & +++ & +++ \\
Streptomycin & +++ & +++ \\
Tetracycline & +++ & ++ \\
\hline
\end{tabular}

a The degree of susceptibility is expressed as ,+++++ , or + , in decreasing order; - , resistant. The amount of antibiotic used and the criteria for determining susceptibility have been previously described (40). 
TABLE 6. $G+C$ contents of the DNAs of the strains studied

\begin{tabular}{lccc}
\hline \multicolumn{1}{c}{ DNA prepared from: } & \multicolumn{1}{c}{ G+C content (mol\%) } \\
\cline { 2 - 4 } & $\begin{array}{c}\text { Melting temper- } \\
\text { ature method }\end{array}$ & $\begin{array}{c}\text { Hydrolysis and } \\
\text { chromatography } \\
\text { method }\end{array}$ & UV spectroscopy \\
\hline "Bordetella pertussis" ATCC 190 & 60 & 59.5 & 59.5 \\
"Bordetella pertussis" ATCC 6627 & 59 & 60 & 61 \\
Bordetella pertussis ATCC 8467, phase I & 68 & 66 & 68 \\
B. pertussis 18323, phase I & 68 & 67 & 67 \\
B.pertussis Sakurayashiki, phase III & 67 & 66 & 67 \\
B. pertussis 3 B, phase III & 70 & 67 & 66 \\
B. pertussis Sakurayashiki, phase IV & 66 & 66 & 67 \\
B. pertussis Kudo, phase IV & 70 & 66 & \\
Bordetella parapertussis 17903 & & & 67 \\
Bordetella bronchicanis 214 & & & \\
\hline
\end{tabular}

TABLE 7. DNA homologies of 11 strains with "Bordetella pertussis" ATCC 190 and Pseudomonas pseudoalcaligenes ATCC 17440

\begin{tabular}{|c|c|c|c|}
\hline \multirow{3}{*}{ Strains tested } & \multicolumn{3}{|c|}{ Homology index $(\%)$} \\
\hline & \multicolumn{2}{|c|}{ ATCC 190} & \multirow{2}{*}{$\begin{array}{l}\text { ATCC } \\
17440 \\
(45 \mathrm{C})\end{array}$} \\
\hline & $45 \mathrm{C}$ & $37 \mathrm{C}$ & \\
\hline $\begin{array}{l}\text { "Bordetella pertussis" } \\
\text { ATCC } 190\end{array}$ & 100 & 100 & 27 \\
\hline $\begin{array}{l}\text { "Bordetella pertussis" } \\
\text { ATCC } 6627\end{array}$ & 99 & 92 & 26 \\
\hline $\begin{array}{l}\text { Pseudomonas pseu- } \\
\text { doalcaligenes } \\
\text { ATCC } 17440\end{array}$ & 17 & 31 & 100 \\
\hline $\begin{array}{l}P . \text { aeruginosa ATCC } \\
10145\end{array}$ & 15 & 22 & 26 \\
\hline $\begin{array}{l}\text { P. fluorescens ATCC } \\
13525\end{array}$ & 11 & 20 & 24 \\
\hline $\begin{array}{l}P . \text { alcaligenes ATCC } \\
14909\end{array}$ & 13 & 22 & 28 \\
\hline $\begin{array}{l}\text { P. maltophilia ATCC } \\
13637\end{array}$ & 8 & 18 & 6 \\
\hline$P{ }_{12633}^{\text {putida }}$ ATCC & 11 & 28 & 19 \\
\hline $\begin{array}{c}\text { Bordetella pertussis } \\
18323, \text { phase I }\end{array}$ & 9 & 15 & 14 \\
\hline $\begin{array}{l}\text { B. pertussis ATCC } \\
8467 \text {, phase I }\end{array}$ & 7 & 12 & 8 \\
\hline $\begin{array}{l}\text { B. pertussis Sakura- } \\
\text { yashiki, phase III }\end{array}$ & 9 & 20 & 13 \\
\hline $\begin{array}{c}\text { B. pertussis Sakura- } \\
\text { yashiki, phase IV }\end{array}$ & 8 & 32 & 16 \\
\hline
\end{tabular}

Kawai (18) described the single polar flagellation of ATCC 190 and ATCC 6627 and proposed that they be placed in the genus Pseudomonas. Aprile (2) suggested that ATCC 190 belongs to Lophomonas (10) because it possesses one or two polar flagella and fails to oxidize glucose. However, Lophomonas is an illegitimate bacterial generic name (7), and Davis and Park (9)

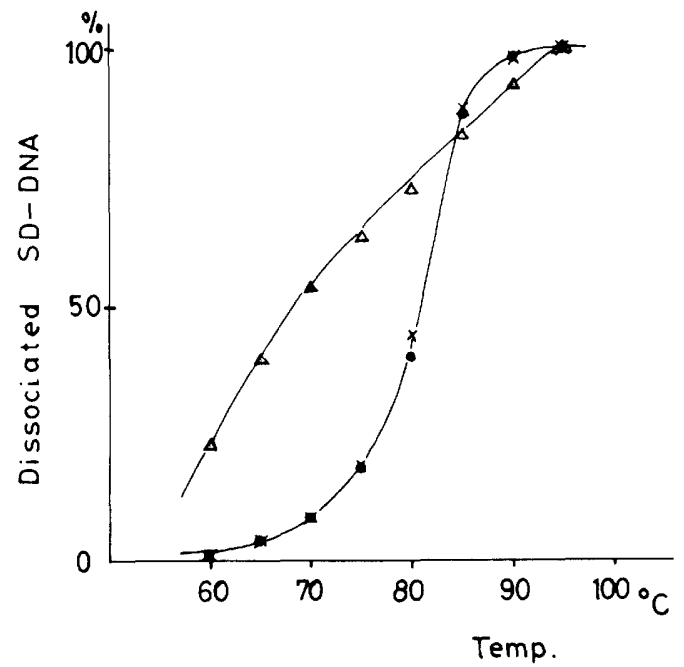

FIG. 2. Thermal dissociation profile of reassociated DNA. Symbols: - homologous DNA (ATCC 6627); $\times$, hybridized DNA between ATCC 6627 and ATCC 190; $\triangle$, hybridized DNA between ATCC 6627 and ATCC 13637. A membrane-bearing reassociated $D N A$ was heated in $0.1 \times S S C$ for 10 min at various temperatures from 60 to $95 \mathrm{C}$ (5 C increments). Dissociated DNA, after addition of carrier DNA, was precipitated with $5 \%$ trichloroacetic acid, collected on a membrane filter, and counted $\left({ }^{14} \mathrm{C}\right.$ radioactivity).

proposed a new generic name, Comamonas, to replace it. Comamonas terrigena (Günther) Hugh (12) is the only species recognized in the genus Comamonas. In contrast to the polar monotrichous morphology of ATCC 190 and ATCC 6627 , the neotype strain for $C$. terrigena has a tuft of polar flagella and produces a basic reaction in oxidation-fermentation basal medium containing glucose or any of 25 other carbon compounds which were tested for ATCC 190 and ATCC 6627. 
Since ATCC 190 and ATCC 6627 are of clinical origin, they were compared with the type or neotype strains of six Pseudomonas species frequently encountered in clinical specimens (1417). DNA-DNA hybridization experiments showed a high degree of homology between ATCC 190 and ATCC 6627 and a low degree of homology between the two strains and four strains of $B$. pertussis or the six Pseudomonas strains (Table 7). Furthermore, the two strains could not be identified as belonging to any of the currently recognized or recently described Pseudomonas species $(3,4,6,11,13,20,25-30$, $34,35,38,40)$.

Thus, strains ATCC 190 and ATCC 6627 appear to belong to a new species, for which we propose the name Pseudomonas pertucinogena (M. L. noun pertucin pertucin, a bacteriocin that inhibits smooth strains of Bordetella pertussis; Gr.v. gennao to produce; M. L. adj. pertucinogenus producing pertucin). ATCC 190 is designated as the type strain for the species.

In closing, it should be noted that although Bordet-Gengou medium was specifically designated for the isolation of $B$. pertussis strains from human respiratory tract specimens, it does not inhibit the growth of all other bacteria in these specimens. Even if the medium contains an appropriate quantity of penicillin to inhibit the growth of gram-positive cocci, it is not a perfect selective isolation medium for $B$. pertussis strains. Bordetella parapertussis, Bordetella bronchicanis, and many other aerobic gram-negative rods grow on Bordet-Gengou medium containing penicillin. Colonies on this medium which resemble those of $B$. pertussis should be transferred to a peptone broth, such as brain heart infusion, without blood or charcoal, and should be identified on the basis of morphological, physiological, and biochemical properties. The slide agglutination test, performed with specific antipertussis serum, is a confirmatory tool for the identification of $B$. pertussis strains.

\section{ACKNOWLEDGMENTS}

We wish to thank M. Okanishi for his useful advice on the DNA homology experiments, R. Hugh for his kind help in the preparation of the manuscript, R. Sakazaki and T. Shimada for their useful suggestions, in the early stage of this study, on the physiological and biochemical experiments, and all those who supplied bacterial strains. Thanks are also due to $\mathrm{H}$. Yabuuchi, Jr., for the preparation of the photomicrographs.

\section{REPRINT REQUESTS}

Address reprint requests to: Yoko Kawai, Department of Bacteriology I, National Institute of Health, 10-35, 2chome, Kamiosaki, Shinagawa-ku, Tokyo, 141, Japan.

\section{LITERATURE CITED}

1. Allen, R. T. L. 1940. The estimation of phosphorus. Biochem. J. 34:858-865.

2. Aprile, M. A. 1972. A reexamination of phase IV Bordetella pertussis. Can. J. Microbiol. 18:1793-1801.

3. Ballard, R. W., M. Doudoroff, and R. Y. Stanier. 1968. Taxonomy of the aerobic pseudomonads: Pseudomonas diminuta and $P$. vesiculare. J. Gen. Microbiol. 53:349-361.

4. Ballard, R. W., N. J. Palleroni, M. Doudoroff, and R. Y. Stanier. 1970. Taxonomy of the aerobic pseudomonads: Pseudomonas cepacia, $P$. marginata, and $P$. caryophylli. J. Gen. Microbiol. 60:199-214.

5. Brenner, D. J., and S. Falkow. 1971. Molecular relationships among members of the Enterobacteriaceae. Adv. Genet. 16:81-118.

6. Buchanan, R. E., and N. E. Gibbons (ed.). 1974. Bergey's manual of determinative bacteriology, 8th ed, p. 217-243. The Williams \& Wilkins Co., Baltimore.

7. Buchanan, R. E., J. G. Holt, and E. F. Lessel. 1966. Index Bergeyana. The Williams \& Wilkins Co., Baltimore.

8. Cohen, S. M., and M. W. Wheeler. 1946. Pertussis vaccine prepared with phase I cultures grown in fluid medium. Am. J. Public Health 36:371.

9. Davis, G. H. G., and R. W. A. Park. 1962. A taxonomic study of certain bacteria currently classified as Vibrio species. J. Gen. Microbiol. 27:101-119.

10. Galarneault, T. P., and E. Leifson. 1956. Taxonomy of Lophomonas n.gen. Can. J. Microbiol. 2:102-110.

11. Hendrie, M. S., and J. M. Shewan. 1966. The identification of certain Pseudomonas species, p. 1-7. In B. M. Gibbs and F. A. Skinner (ed.), Identification methods for microbiologists. Academic Press, London.

12. Hugh, R. 1962. Comamonas terrigena comb. nov. with proposal of a neotype and request for an opinion. Int. Bull. Bacteriol. Nomencl. Taxon. 12:33-35.

13. Hugh, R. 1970. Pseudomonas and Aeromonas, p. 175190. In J. E. Blair, E. H. Lennette, and J. P. Truant (ed.), Manual of clinical microbiology. American Society for Microbiology, Bethesda, Md.

14. Hugh, R., L. Guarraia, and H. Hatt. 1964. The proposed neotype strains of Pseudomonas fluorescens (Trevisan) Migula 1895. Int. Bull. Bacteriol. Nomencl. Taxon. 14:145-155.

15. Hugh, R., and P. Ikari. 1964. The proposed neotype strain of Pseudomonas alcaligenes Monias 1928. Int. Bull. Bacteriol. Nomencl. Taxon. 14:103-107.

16. Hugh, R., and E. Leifson. 1963. A description of the type strain of Pseudomonas maltophilia. Int. Bull. Bacteriol. Nomencl. Taxon. 13:133-138.

17. Hugh, R., and E. Leifson. 1964. The proposed neotype strains of Pseudomonas aeruginosa (Schroeter 1872) Migula 1900. Int. Bull. Bacteriol. Nomencl. Taxon. 14:69-84.

18. Kawai, Y. 1972. Identification of the bacteria which produces a bacteriocin active against phase I Bordetella pertussis. Jpn. J. Bacteriol. 27:309.

19. Kawai, Y. 1974. Purification and characterization of pertucin produced by Pseudomonas pertucinogena. Antimicrob. Agents Chemother. 6:347-359.

20. King, E. O. 1964. The identification of unusual pathogenic Gram-negative bacteria. Center for Disease Control, Atlanta, Ga.

21. Litkenhous, C., and P. V. Liu. 1967. Bacteriocin produced by Bordetella pertussis. J. Bacteriol. 93:14841488.

22. Marmur, J., and P. Doty. 1962. Determination of the base composition of deoxyribonucleic acid from its thermal denaturation temperature. J. Mol. Biol. 5:109-118. 
23. Nakamura, M. 1950. Colorimetric determination of phosphorus. Nippon Nogei Kagaku Kaishi (In Japanese) $24: 1-5$.

24. Okanishi, M., and K. F. Gregory. 1970. Methods for determination of deoxyribonucleic acid homologies in Streptomyces. J. Bacteriol. 104:1086-1094.

25. Palleroni, N. J., R. W. Ballard, Ericka Ralston, and M. Doudoroff. 1972. Deoxyribonucleic acid homologies among some Pseudomonas species. J. Bacteriol. 110:1-11.

26. Palleroni, N. J., M. Doudoroff, R. Y. Stanier, R. E. Solanes, and M. Mandel. 1970. Taxonomy of the aerobic pseudomonads: the properties of the Pseudomonas stutzeri group. J. Gen. Microbiol. 60:215-231.

27. Pedersen, M. M., E. Marso, and M. J. Pickett. 1970. Nonfermentative bacilli associated with man. III Pathogenicity and antibiotic susceptibility. Am. J. Clin. Pathol. 54:178-192.

28. Pickett, M. J., and M. M. Pedersen. 1970. Characterization of saccharolytic nonfermentative bacteria associated with man. Can. J. Microbiol. 16:351-362.

29. Ralston, E., N. J. Palleroni, and M. Doudoroff. 1973. Pseudomonas picketti, a new species of clinical origin related to Pseudomonas solanacearum. Int. J. Syst. Bacteriol. 23:15-19.

30. Rogul, M., J. J. Brendle, D. K. Haapala, and A. D. Alexander. 1970. Nucleic acid similarities among Pseudomonas pseudomallei, Pseudomonas multivor. ans, and Actinobacillus mallei. J. Bacteriol. 101:827835.

31. Saito, H., and K. Miura. 1963. Preparation of transforming deoxyribonucleic acid by phenol treatment.
Biochim. Biophys. Acta 72:619-629.

32. Shewan, J. M., and W. C. Haynes. 1967. Report of the subcommittee on Pseudomonas and related organisms (1962-1966). Int. J. Syst. Bacteriol. 17:255-259.

33. Silvestri, L. G., and L. R. Hill. 1965. Agreement between deoxyribonucleic acid base composition and taxometric classification of gram-positive cocci. J. Bacteriol. 90:136-140.

34. Stanier, R. Y., N. J. Palleroni, and M. Doudoroff. 1966. The aerobic pseudomonads: a taxonomic study. J. Gen. Microbiol. 43:159-271.

35. Stutter, V. L. 1968. Identification of Pseudomonas species isolated from hospital environment and human sources. Appl. Microbiol. 16:1532-1538.

36. Toyama, H., M. Okanishi, and H. Umezawa. 1974. Heterogeneity among whorl-forming streptomycetes determined by DNA reassociation. J. Gen. Microbiol. 80:507-514.

37. Ulitzur, S. 1972. Rapid determination of DNA base composition by ultraviolet spectroscopy. Biochim. Biophys. Acta 272:1-11.

38. Weaver, R. E., H. W. Tatum, and D. G. Hollis. 1972. The identification of unusual pathogenic gram-negative bacteria (Elizabeth $O$. King). Preliminary revision. Center for Disease Control, Atlanta, Ga.

39. Wyatt, G. R., and S. S. Cohen. 1953. The bases of the nucleic acids of some bacterial and animal viruses: the occurrence of 5-hydroxymethylcytosine. Biochem. J. 55:774-782.

40. Yabuuchi, E., and A. Ohyama. 1972. Characterization of pyromelanin producing strains of Pseudomonas aeruginosa. Int. J. Syst. Bacteriol. 22:53-64. 